\title{
Metallothionein Expression in Estuarine Catfish (Arius thalassinus) Kidney on Exposure to Heavy Metals (Cd, Pb, $\mathrm{Cu}$ and Zn) Concentration
}

\author{
* Ahmed, A., Ismail, A., Omar, H., Zulkifli, S., Yusof, S. and Rahman, F. \\ Department of Biological Science, Faculty of Science, Universiti Putra Malaysia, \\ 43400 UPM Serdang, Selangor, Malaysia \\ *Corresponding author: aismail@upm.edu.my
}

\begin{abstract}
Immunohistochemical techniques have been used to identify Metallothionein3 (MT3) expression specifically to detect MT3 levels in the kidney. The techniques employed are highly sensitive, thus allowing the detection of very low amount of proteins with the use of antibodies. The present study aimed at identifying the MT3 expressions and localizations in the kidney tissue of estuarine catfish Arius thalassinus from Kuala Gula using immunohistochemical methods. Primary mouse monoclonal anti-MT3 (1F11), primary antibody (1:2000), secondary antibody and Goat anti-mouse IgG2 (1:2000) were used. MT3 bands were detected using (Santa Cruz kit USA method). Heavy metals (Cd, $\mathrm{Pb}, \mathrm{Zn}$ and $\mathrm{Cu}$ ) were determined using aqua regia's methods followed by analyses with AAS. The results showed high expressions of Metallothionein3 (MT3) with an increasing concentration of heavy metals. Large catfish A. thalassinus had higher accumulation of heavy metals concentrations therefore, exhibiting higher expressions than smaller sized fish. The concentration of heavy metals in fishes were: $\mathrm{Zn}(284.00 \pm 29.7,259.32 \pm 23.2$

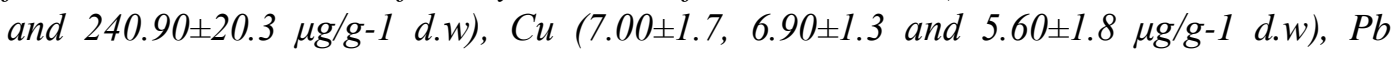
$(66.80 \pm 10.8,35.31 \pm 6.4$ and $26.02 \pm 6.9 \mu \mathrm{g} / \mathrm{g}-1 \mathrm{~d} . \mathrm{w})$ and $C d(1.32 \pm 0.12,1.19 \pm 0.12$ and $1.20 \pm 0.09 \mu \mathrm{g} / \mathrm{g}-1 \mathrm{~d} . \mathrm{w})$ in large, medium and small fish respectively. The results of this study suggests it suitability as biomarker candidate for pollution assessment in the aquatic environment. The different MT3 expressions in different sized fish and different polluted places showed the potential use of MT3 as biomonitoring biomarker for heavy metals exposure in an aquatic environment.
\end{abstract} Keywords: Metallothionein3; Immunohistochemistry; Arius thalassinus; Heavy
metals; Kidney

\section{INTRODUCTION}

Toxicity of Heavy metals in fish as aquatic organism and their dangers were reported by many researchers from Malaysia [1,2,3,4,5,6,7,8,9,10].

Most of the aquatic organisms were reported to accumulate heavy metals in their tissues. Consequently, fish is considered as one of the aquatic pollutant recipients and can accumulate a significant heavy metals concentration in their tissues [11, 12]. Since fish is consumed by a significant number of the human population worldwide as part of their diet, they are considered the top consumers according to the food chain hierarchy. Accumulation of heavy metals in the human body is capable of posing chronic toxicity if their levels exceed the concentration levels necessary for body metabolisms. Biomarkers being sensitive indicators of early effects of heavy metals in the coastal environment are considered useful tools for monitoring some pollution effects. Any pollutant is a potential inducer of stress in ecosystem biota[13]. Therefore, in order to get a better monitoring 
perspective and showing a clear picture of the damage of the heavy metal, the use of metallothioneins, MT3 as biomarker can be a complementary technique to evaluate the extent of pollution in the affected areas and assess the level of concentration and accumulation of heavy metals in the animal's tissues [14]. Therefore, expression is generally used to illustrate animals' cellular stress indicators as well as the intracellular signal for induction.

Methallothionein-3 (MT3) is known as a growth inhibitory factor, hence, recent studies have shown its ability of Metallothionein3 (MT3) expression in different organs such as the stomach, heart, kidney, and reproductive system [15,16]. MT3 has metal bonding properties with the highest affinity to $\mathrm{Cu}, \mathrm{Zn}, \mathrm{Cd}$ and $\mathrm{Pb}[14,17,18]$, and indicating acute inflammation stress of cells in animals $[19,20]$ when compared to MT1 and MT2. This protein provide protection against oxidative stress [21, 22]. The ability MT3 to bind to heavy metal renders the MT3 an important mediator or reduced heavy metal-induced toxicity. Previous studies suggested Metallothionein3 (MT3) as a good biomarker for pollution in the environment $[12,20]$ and can be indicated as antioxidants having the potentials of reducing several pathologic processes in the chemotherapy treatment of tumor cell resistance[14]. Furthermore, several methods have been developed for Metallothionein3 (Mt3) detection such as the spectrophotometric method, western blotting method, RT-PCR method as well as immunohistochemical method [18]. Immunohistochemistry (IHC) is a method which is a combination of three techniques known as biochemical, immunological and anatomical in order to provide image of the discrete components found in tissues through the use of appropriately-labelled antibodies to bind specifically to their target antigens in situ. Due to its advantages, this method can detect the affected tissues through the use of antibodies [20]. It is very sensitive in detecting proteins which binds to specific antibodies, thereby allowing the production of a clearer picture of the Metallothionein3 (MT3) expression inside the organs. In addition, an antibody is conjugated to an enzyme, such as peroxidase. This peroxidase can catalyze a color-producing reaction. Lastly, the accumulation of the following metals $\mathrm{Zn}, \mathrm{Cu}, \mathrm{Cd}$, and $\mathrm{Pb}$ induced Metallothionein3 (MT3) in different organs of catfish such as liver, gill, and kidney. The immunohistochemistry studies were conducted to determine the possible impact of contamination due to the presence of heavy metal in different tissues. Health condition of the environmental caused by anthropogenic impacts is usually monitored using aquatic organisms. The main objective for this study is to identify the Metallothionein3 (MT3) expressions and localizations in the kidney of different sized estuarine catfish Arius thalassinus and examine the responses due to stress obtained from Kuala Gula area using a biomarker to assess the fish's response to exposure to heavy metals ( $\mathrm{Zn}, \mathrm{Cu}, \mathrm{Pb}$, and $\mathrm{Cd}$ ) by using immunohistochemical methods.

\section{MATERIALS AND METHODS}

\subsection{Experimental design}

The estuarine catfish Arius thalassinus were collected from Kuala Gula at ( $\mathrm{N}$ 410816'90"' N 40563/750 to E 10110854320”- E 100o28/47.89”), Perak, Malaysia. Thirty samples of fishes were caught by fishermen. Three different sizes were categorized as indicated in (Table1) and Chrysochir aureus (fish with low heavy metals content) served as reference fish also obtained were by fishermen in the respective areas of this study. The samples collected were placed in separate labelled clean polyethylene bags, stored in an ice-chest and transported to the laboratory for further analysis. 
Table 1. Length and Weight of Small, Medium and LargeArius thalassinus

\begin{tabular}{lcc}
\hline Size group & Length $(\mathrm{cm})$ & Weight $(\mathrm{g})$ \\
\hline Small & $13.0-16.5$ & $29.3-59.5$ \\
Medium & $17.0-19.7$ & $41.0-72.3$ \\
Large & $21.0-25.5$ & $165.0-201.7$ \\
\hline
\end{tabular}

\subsection{Heavy metal analysis}

All the samples of catfish $A$. thalassinus were dissected with clean stainless steel dissecting apparatus. Kidney tissues were removed following [23], [24]and [25]. All the samples were oven-dried at $60^{\circ} \mathrm{C}$ for $72 \mathrm{~h}$ or until achieving a constant dry weight (dw). About $0.5 \mathrm{~g}$ dried tissue sample was taken from each plus $10 \mathrm{ml}$ of HNO3 (AnalaR Grade, $\mathrm{BDH} 69$ \%) were digested and stored. Heavy metals concentration ( $\mathrm{Zn}, \mathrm{Cu}, \mathrm{Pb}$ and $\mathrm{Cd}$ ) determination was carried out by an air-acetylene flame atomic absorption spectrophotometer (AAS, Perkin-Elmer Model Analyst 800, Shelton, CT, USA). For immunohistochemistry studies, five specimens for each small, medium and large Arius thalassinus and Chrysochir aureus were used.

\subsection{Immunoperoxidase Staining}

Immunohistochemical evaluation of MT3 was performed as described by [13, 20] and determined at 48 hours following five micrometre thick paraffin sections through matched coronal levels of the MT3 stained with Mouse monoclonal anti-MT3 (1F11) primary antibody (1:2000) with the aid of standard immunoperoxidase techniques. Briefly, paraffin sections of fish gill and liver were deparaffinization and rehydration in decreasing alcohol dilution with distilled water. For antigen retrieval, all the slides were put in a solution consisting of $150 \mu \mathrm{l}$ of trypsin plus $150 \mathrm{ml}$ of PBS and then put in the oven for 15 min $37^{\circ} \mathrm{C}$. The samples were incubated for $5 \mathrm{~min} 15 \mathrm{ml}$ in PBS three times. All the samples were incubated with a 3.0\% hydrogen peroxide, then all samples incubated for one hour in $1.5 \%$ blocking serum; in this step, $75 \mu$ l normal blocking serum combined with 5ml PBS. After that, it was washed with PBS for $15 \mathrm{~min}$, 5min for each. MT3 immunoreactivity was detected with a conjugated horseradish peroxidase (HRPconjugated) IgG secondary antibody at 1:2000 dilutions and ImmunoCruz mouse ABC Staining kit. We counterstaining all slides with Mayer's haematoxylin visualized in light microscopy.

\subsection{Statistical Analyses}

The data were analyzed using One way ANOVA procedure of the Statistical Package of Social Science (IBM SPSS) package (IBM Corp. IBM SPSS Statistics for Windows, Version 22.0. Armonk, NY: IBM Corp.). For simple analysis of few parameters, parametric analysis using statistical package SPSS version 22 was employed[26]. The significance was reported at $\mathrm{P}<0.05$ levels. However, in the field, multiple parameters interact with each other with varying degrees. Hence, non-parametric statistics were employed [27, 28, 29]. Non-parametric analysis using ranked value was used to indicate the expression in different species, different sizes, and different organs. $\mathrm{P}<0.05$ was considered statistically significant. The rank-based analysis offers alternative methods to interpret complex multi-parameter data that do not require the data to be normally distributed and in the presence of outliers. With this approach, the effect of outliers can be minimized, plus any problem of skewness is avoided because all rank is equally distanced from each other. The main aim of the present study is to observe the trend and relationship 
between different parameters, their overall interactions with variables. Therefore, if the data are handled non-parametrically, those issues can be elucidated clearly.

\section{RESULTS AND DISCUSSION}

\subsection{Heavy Metals Accumulation in Different Fish Size and Tissues:}

The results showed Zinc (Zn) concentrations were highest in all tissues in different sizes of kidney tissues, moderate for $\mathrm{Pb}$, and $\mathrm{Cd}$ was the lowest (Table 2). Large catfish $A$. thalassinus exhibited a higher accumulation of heavy metals than medium and small. The concentration of heavy metals fishes were as follows: Zn (284.00 $\pm 29.7,259.32 \pm 23.2$ and $240.90 \pm 20.3 \mu \mathrm{g} / \mathrm{g}-1$ d.w), $\mathrm{Cu}(7.00 \pm 1.7,6.90 \pm 1.3$ and $5.60 \pm 1.8 \mu \mathrm{g} / \mathrm{g}-1 \mathrm{~d} . \mathrm{w}), \mathrm{Pb}$ (66.80 $\pm 10.8,35.31 \pm 6.4$ and $26.02 \pm 6.9 \mu \mathrm{g} / \mathrm{g}-1 \mathrm{~d} . \mathrm{w})$ and $\mathrm{Cd}(1.32 \pm 0.12,1.19 \pm 0.12$ and $1.20 \pm 0.09 \mu \mathrm{g} / \mathrm{g}-1 \mathrm{~d} . \mathrm{w})$ in large, medium and small fishrespectively.

Table 2: Mean Concentration of $\mathrm{Zn}, \mathrm{Cu}, \mathrm{Pb}$ and $\mathrm{Cd}$ in different Size of Kidney of Small, Medium, And LargeA. thalassinus ( $\mu \mathrm{g} / \mathrm{g} \mathrm{d.w} \pm \mathrm{SD}$ )

\begin{tabular}{ccc}
\hline Small & Medium & Large \\
\hline $240.90 \pm 20.3$ & $\mathbf{Z n}$ & \\
$(1)$ & $259.32 \pm 23.2$ & $284.00 \pm 29.7$ \\
& $(2)$ & $(3)$ \\
$5.60 \pm 1.8$ & $\mathrm{Cu}$ & $7.00 \pm 1.7$ \\
$(1)$ & $6.90 \pm 1.3$ & $(3)$ \\
& $(2)$ & \\
$26.02 \pm 6.9$ & $\mathrm{~Pb}$ & $(3)$ \\
$(1)$ & $35.31 \pm 6.4$ & $(2)$ \\
& $\mathrm{Cd}$ & $1.32 \pm 0.12$ \\
$1.20 \pm 0.09$ & $1.19 \pm 0.12$ & $(3)$ \\
$(1)$ & $(2)$ & \\
\hline
\end{tabular}

Remark: Value in bracket is ranked value. High value gets the highest score. 10 specimens of each size for each species

Present work have demonstrated that heavy metals contamination in the river in fish from Kuala Gula and the contaminations were slightly higher (Table 2) due to human activities in this river [4, 30]. From this study, large fish size showed higher accumulation of heavy metals similarly reported by $[31,32,33]$ where the heavy metals concentration increase with increasing age or size.

Zinc (Zn) register a higher accumulation in the kidney of large fish, while $\mathrm{Cu}$ accumulation was lower. There is the possibility that $\mathrm{Cu}$ metal was either completely removed or excreted through gills, kidney or liver tissues of $A$. thalassinus through specific metabolism process and coenzyme catalysts reaction taking place in the kidney [34].

From the results, $\mathrm{Pb}$ showed the second-highest accumulation while Cd was the lowest in the kidney of fish. Similar results were also reported by [35]who reasoned that an increase 
in heavy metals concentration such as $\mathrm{Pb}$ and $\mathrm{Cd}$ in Kuala Gula was due to an increase in human activities coinciding with the period of the annual migration of birds from January to April. A large number of tourists visited this area to watch the migratory birds. Their use of boats and vehicles contributed significantly to the pollution of the river.

\subsection{Expression of Metallothionein3 (MT3)}

From the results, the expression of Metallothionein3 (MT3) (indicated by brown color) in catfishes A. thalassinus of different sizes, of catfish, kidney of large fish showed higher expression than the medium and small-sized fish. The kidney of reference fish (Chrysochir aureus) however exhibited negative expressions (absent of brown color) due to low concentrations of $\mathrm{Zn}, \mathrm{Cu}, \mathrm{Pb}$ and $\mathrm{Cd}$ heavy metals than in two species of catfish (Figure 1).

Most Metallothionin3 (MT3) protein expression indicated in the kidney was in cytoplasm, renal corpuscles, and renal tubules. It was progressively positive from mild, moderate to severe expression. 

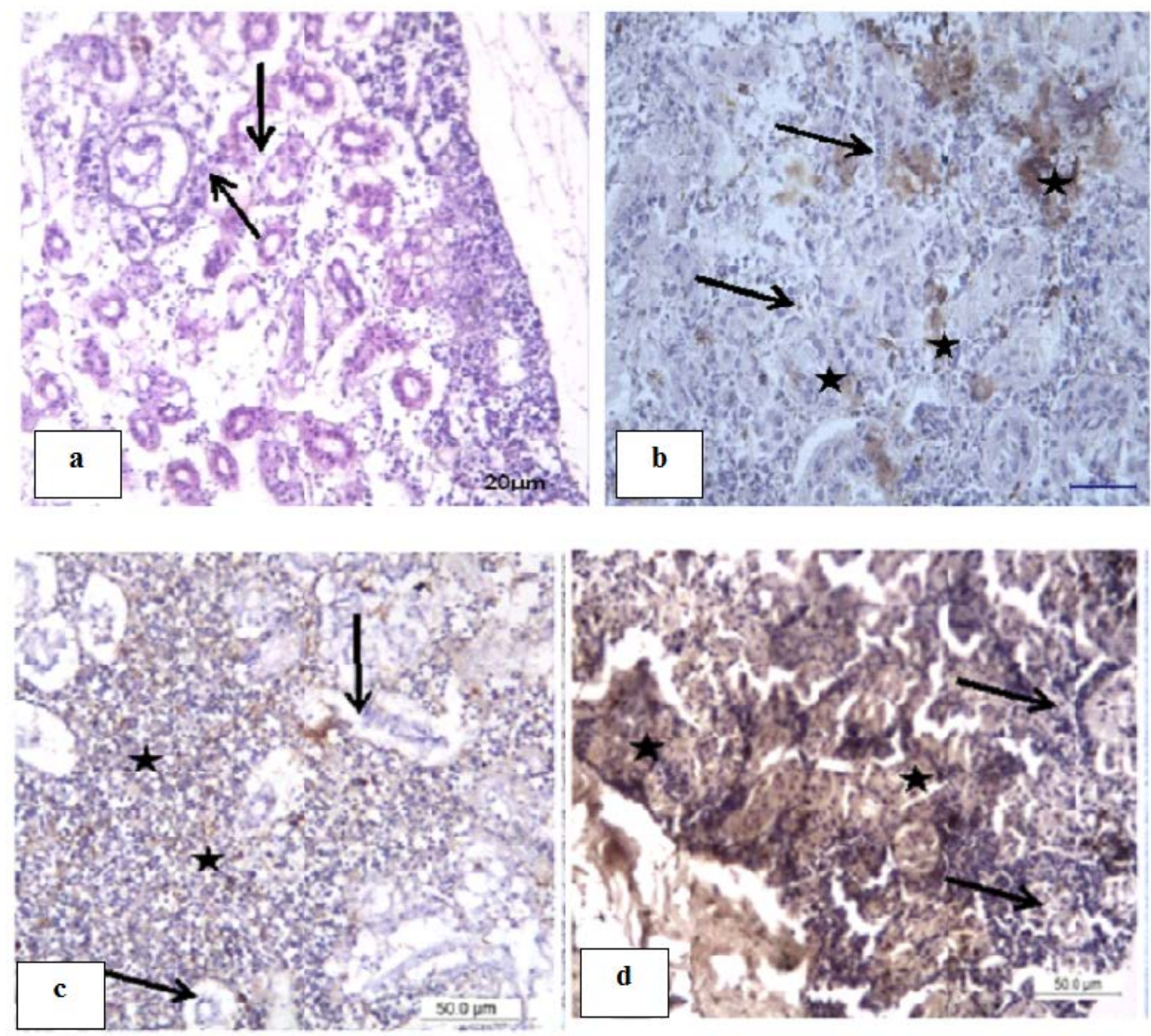

Figure 1: Kidney of reference fish Chrysochir aureus (a) renal corpuscle and renal tubule showing negative expression of MT3 (arrows); (b) small catfish $A$. thalassinus, positively expression of MT3 and immunolocalization in cytoplasm of kidney (stars) and renal tubules (arrows); (c ) Positively expression of MT3 on medium catfish $A$. thalassinus from Kuala Gula, cytoplasm of kidney (stars) and renal tubules (arrows); (d) Positive expression of MT3 on large cat fish A. thalassinus in renal tubule (arrows), cytoplasm and around renal tubule (stars) from Kuala Gula, Scale bars: $20(a, b)$ and $50(c, d) \mu \mathrm{m}$.

The results of this study showed that Metallothionein3 (MT3) expressions were present in different tissues of (small, medium and large) catfish. Large A. thalassinus showed more intense expression of Metallothionein3 (MT3) than other size categories, most likely due to higher heavy metals accumulation in the tissues. However, in Chrysochir aureus as a reference fish, the metal concentration was low and the MT3 induction was absent. A similar result was also reported by [36], suggesting that MT3 expression increased with increasing age which corresponding with the fish's size. They speculated that the mechanism of MT3 homeostasis is related to the control and regulation of heavy metal and toxic substances.

The tissues with MT3 induction through the activation of MT3 protein was indicated in the form of brown color. In the reference fish group, Chrysochir aureus although the specie was different from the test fish, living in different niche and with different feeding habit, fish was low in heavy metal content and therefore did not show MT3 induction. It is very likely that low heavy metal concentration did not activate MT3 protein, hence this fish exhibit negative expression with MT3 
The higher level of MT3 in the tissues of fish that was exposed to effluent may suggest adaptation mechanisms developed by stressed fish via isolating undesirable metal load. The presence of brown morphology indicated that cells have activated the protein MT3 in the organs of fish. The higher concentration and higher binding effects of $\mathrm{Zn}, \mathrm{Pb}, \mathrm{Cu}$ and $\mathrm{Cd}$, the higher bioaccumulation and biomagnification formation through the food chain in their tissues. The effects of heavy metals $\mathrm{Cu}, \mathrm{Zn}, \mathrm{Cd}$, and $\mathrm{Pb}$ in water and sediment can also be reflected through MT3 expression in both species investigated. The presence of brown tissues in the different size of kidney clearly demonstrates the high presence of activation MT3 protein.

Increased concentration of heavy metal leads to a change in cell structure and this might be related to the protection strategy of $A$. thalassinus in response to stress from heavy metal accumulation. Activation of MT3 protein in A. thalassinus gradually developed in conjunction with steady increase in heavy metal concentration. The phenomenon was validated in the present study by the activation of MT3 protein in the two catfish species. Similar finding was reported by [37]who mentioned that Metallothionein expression in fish is often associated with the organs involved in metal uptake, metabolism, and excretion which is the kidney. Another study by [38]stated that significant cellular protective processes could be linked with metallothionein proteins. Such cellular protective processes include; protection against immunotoxins, hemotoxins, nephrotoxins and inactivation of hydroxyl radicals.

Consequently, through the choice of $A$. thalassinus, good experimental design, and right tissues to be analyzed, MT3 concentration can be regarded as the most reliable biomarker, signifying that a cell is responding to an increased trace metals exposure. Furthermore, an increase in heavy metal concentration might be linked to diverse kinds of anthropogenic discharged from industrial and domestic wastes that were not properly treated in the vicinity of the river [38].

The role of MT complexes in the tissue of a fish is to deactivate excess load of heavy metal through detoxifying its antagonistic influence in the fish biosystem flourishing in the stress environment (ambient water) containing toxic metals [39]. Lee et al. [40], stated that kidney tissues are the target organs possibly as a result of their functions in detoxifying and releasing toxic substances in the body of organisms. Chronic exposure to $\mathrm{Pb}$ in these organs caused a high accumulation of $\mathrm{Pb}$. The further increment can disturb the balance of antioxidants and capable of triggering oxidative stress. $\mathrm{Pb}$ poisoning and induced stress progressively increased antioxidant responses. Additionally, when the fish was exposed to $\mathrm{Pb}$, it will cause toxicity effects to membrane function and structure due to its high affinity to red blood cells, which increases vulnerability to oxidative stresses. Many biological variables, such as age and sex, can also influence MT induction, thus increasing the variability of the response [41].

Waterborne $\mathrm{Pb}$ exposure pathway mostly entered via the gills, while dietary pathway entered through other internal target tissues [40]. However, MT3 is increasing its expression in parenchymal tissues because they have a very active mechanism for accumulation, metabolizing, and depuration of metals [42]. These are the logical reasons for the increase of MT3 expressions in the kidney. Sow et al. [10], reported an increase of MT expressions in the liver than gills because the liver serves as metals storage that is required by enzymes and metabolic function and detoxification roles.

Among the heavy metals studied, $\mathrm{Cd}$ and $\mathrm{Pb}$ are nonessential, thus more disruptive than $\mathrm{Cu}$ and $\mathrm{Zn}$ and MT is also involved in the metabolism of zinc and copper [43].

Present findings have shown that the activation of MT3 protein progressively increased with increasing heavy metals $(\mathrm{Zn}, \mathrm{Cu}, \mathrm{Pb}$, and $\mathrm{Cd})$ concentration. It became apparent that cells experiencing activation of MT3 protein exhibiting brown color, spreading and forming cell groups.

The immune labelling present in kidney tissues after heavy metals $(\mathrm{Zn}, \mathrm{Cu}, \mathrm{Pb}$, and $\mathrm{Cd})$ exposure was higher than in reference fish. With immunohistochemistry techniques, the cells undergoing activation of MT3 protein will produce brown color formation which 
spreads and later forming cell groups (Figure 1). With respect to the increasing concentration of $\mathrm{Zn}, \mathrm{Cu}, \mathrm{Cd}$, and $\mathrm{Pb}$ heavy metal, the brown coloration expression in the kidney cell, liver and gill also increased in its intensity indicating higher manifestation of activation protein MT3 [44, 45]. Furthermore, the increase in the concentration of heavy metal also resulted in changes in the cell structure and could be linked to a protective strategy in defense against stress due to the build-up of heavy metal. There is a strong correlation that a high concentration of heavy metals results in the high development of activation protein MT3 [46, 47].

As mentioned earlier, urbanization activities, animal production, processing industries, manufacturing industry and agriculture/agro-based industries were among the important sources of heavy metals contamination into the river. As such, the localization and the expression of individual MT isoforms are also intracellular variations. This metallothioneins isoform differs from the common MT in the regulation of gene, transcriptional regulation during development as well as the phenotype of transgenic animals. MT3 correspondingly possessed metal-binding characteristics with the highest affinity to $\mathrm{Cu}, \mathrm{Zn}$, and $\mathrm{Cd}$. The study of the metal binding property of MT3 revealed that MT3 has a bigger affinity compared to MT1 and MT2. Furthermore, detection and quantification of MT were not easy to perform due to low molecular mass and comparatively high content of cysteine [16].

\section{CONCLUSION}

The increasing of differential MT3 expressions in different sized fish with increasing accumulation of heavy metals may indicate the versatility of MT3 as a biomarker tool of biomonitoring heavy metals exposure in an aquatic system. The increasing of protein of Metallothionein3 presence inside the cells to protect the animals from the toxicity of metals as Metallothionein3 (MT3) is expressed mostly in brain tissue but is also able to be detected in another organ such as the kidney.

The additional advantage is that the use of Metallothionein3 (MT3) provides a graphic expression of biomarker that is beneficial in providing a better understanding of the impact of pollutions at the cellular level and heavy metals contamination in rivers.

The difference in the characteristic of localization/induction of MT3 in various cell types as stated in the present study may suggest that the specific expression of MT3 quantification could be adopted in bio-monitoring programs as a biomarker of $\mathrm{Zn}, \mathrm{Cu}, \mathrm{Pb}$ and Cd heavy metals exposure in aquatic environments.

\section{ACKNOWLEDGEMENT}

The team of this work acknowledged the contribution of Special thanks to Universiti Putra Malaysia for providing sampling and infrastructural support. In addition, we wish to express sincere gratitude to the Yemen government and Thamar University for their support.

\section{REFERENCES}

[1] A. Ismail and S. Yusof, "Effect of mercury and cadmium on early life stages of Java medaka (Oryzias javanicus): a potential tropical test fish”. Marine pollution bulletin, vol. 63, no.5-12, (2011), pp. 347349.

[2] F. Mohamat-Yusuff, L.S. Yun, E.C. Wan and S.Z. Zulkifli. "Profile of heavy metals level in catfish (Hexanematichthys sagor) and green mussel (Perna viridis) from Kong Kong Laut, Johor Straits”. Acta Biol Malaysia, vol. 4(2015), pp. 46-50. 
[3] T. R. I. Buhari, and A. Ismail, "Correlations between Geo-Chemical Speciation of Heavy Metals (Cu, Zn, $\mathrm{Pb}, \mathrm{Cd}$ and $\mathrm{Ni}$ ) in Surface Sediments and Their Concentrations in Giant Mudskipper (Periophthalmodon schlosseri) Collected from the West Coast of Peninsular Malaysia”. Journal of Geoscience and Environment Protection, vol. 4, no. 01,(2016), pp. 28-36.

[4] F. Rahman, A. Ismail, H. Omar andM.Z. Hussin, "Exposure of the endangered Milky stork population to cadmium and lead via food and water intake in Kuala Gula Bird Sanctuary, Perak, Malaysia". Toxicology Reports, vol. 4, no. 3,(2017),pp. 502-506.

[5] N.A. Bakar, N.S.A.M. Sata, N.F. Ramlan, W.N.W. Ibrahim, S.Z. Zulkifli, C.A.C. Abdullah andM. N. A. Amal, "Evaluation of the neurotoxic effects of chronic embryonic exposure with inorganic mercury on motor and anxiety-like responses in zebrafish (Danio rerio) larvae". Neurotoxicology and teratology, vol. 59, (2017), pp. 53-61.

[6] F. Z. Abd Aziz, S. Z. Zulkifli, F. Mohamat-Yusuff, M. N. A. Azmai andA. Ismail, “A histological study on mercury-induced gonadal impairment in Javanese medaka (Oryzias javanicus)”. Turkish Journal of Fisheries and Aquatic Sciences, vol. 17, no. 3,(2017), pp. 621-627.

[7] F. Mohamat-Yusuff,A.G. Sarah-Nabila, S.Z. Zulkifli, M. N. A. Azmai, , W. N. W. Ibrahim, S. Yusof andA. Ismail "Acute toxicity test of copper pyrithione on Javanese medaka and the behavioural stress symptoms”. Marine pollution bulletin, vol. 127,(2018), pp. 150-153.

[8] N. A. Alrabie, F. Mohamat-Yusuff, R. Hashim, Z. Zulkeflee, A. Arshad and M. N. A. Amal, "Heavy Metals Concentrations in Stormwater and Tilapia Fish (Oreochromis Niloticus) in Kuala Lumpur Holding and Storage SMART Ponds”. Pertanika Journal of Tropical Agricultural Science, vol. 42, no. 1, (2019), pp. 225-236.

[9] A. Y. Sow, A. Ismail, S.Z. Zulkifli, M.N. Amal andK.A. Hambali, "Survey on heavy metals contamination and health risk assessment in commercially valuable Asian swamp eel, Monopterus albus from Kelantan, Malaysia”. Scientific reports, vol. 9, no. 1, (2019), pp. 1-10.

[10] A. Y., Sow, A. Ismail, S.Z. Zulkifli, M.N. Amal and K. Hambali, "Seasonal variation of heavy metals and metallothionein contents in Asian swamp eels, Monopterus albus (Zuiew, 1793) from Tumpat, Kelantan, Malaysia”. BMC Pharmacology and Toxicology, vol. 20, no 1, (2019), pp. 1-8.

[11] E. Padmini andM.U. Rani, “Comparative biochemistry and physiology, part B impact of seasonal variation on HSP70 expression quantitated in stressed fish hepatocytes”. Comparative Biochemistry and Physiology Part B: Biochemistry and Molecular Biology, vol. 151, no. 3, (2008), pp. 278-285.

[12] S. Fasulo, A. Mauceri, M. Maisano, A. Giannetto, V. Parrino, F. Gennuso and A. D’Agata, “Immunohistochemical and molecular biomarkers in Coris julis exposed to environmental contaminants”. Ecotoxicology and Environmental Safety, vol. 73, no. 5, (2010), pp. 873-882.

[13] S. Rajeshkumar andN. Munuswamy, "Impact of metals on histopathology and expression of HSP 70 in different tissues of Milk fish (Chanos chanos) of Kaattuppalli Island, South East Coast, India”. Chemosphere, vol. 83, no. 4, (2011), pp. 415-421.

[14] S. H., Garrett, M.A. Sens, J.H. Todd, S. Somji and D.A. Sens, "Expression of MT-3 protein in the human kidney”. Toxicology Letters, vol. 105, no. 3, (1999), pp. 207-214.

[15] C.S. Bathula, "The Role of Metallothionein-3 in the Regulation of Cell Differentiation (Doctoral dissertation, University of North Dakota)(2010).

[16] V. Adam, D. Chudobova, K. Tmejova, K. Cihalova, S. Krizkova, R. Guran andM. Konecna,. “An effect of cadmium and lead ions on Escherichia coli with the cloned gene for metallothionein (MT-3) revealed by electrochemistry”,Electrochimica Acta, vol. 140,(2014), pp. 11-19.

[17] C. Hogstrand andC. Haux, "Binding and detoxification of heavy metals in lower vertebrates with reference to metallothionein”,Comparative Biochemistry and Physiology. Part C, Comparative, vol. 100, no. 1\&2, (1991), pp. 137-141.

[18] F. Shariati andS. Shariati, "Review on methods for determination of metallothioneins in aquatic organisms”,Biological Trace Element Research, vol. 141, no. 1\&3, (2011), pp. 340-366.

[19] N. Thirumoorthy, K.T.M. Kumar, A.S. Sundar, L. Panayappan andM. Chatterjee, "Metallothionein : An overview”, World Journal of Gastroenterology, vol. 13, no. 7,(2007),pp. 993-996.

[20] R. Mani, B. Meena andK. Valivittan, "Metallothionein expression in marine catfish (Arius arius) liver on exposure to cadmium using immunohistochemistry and western blot”,International Journal of Pharmacy and Pharmaceutical Sciences, vol. 6, no. 2, (2014), pp. 818-821.

[21] E.A. Ostrakhovitch, Y.P. Song andM.G. Cherian,"Basal and copper-induced expression of metallothionein isoform 1,2 and 3 genes in epithelial cancer cells: The role of tumor suppressor p53”, Journal of Trace Elements in Medicine and Biology, vol. 35, (2016), pp. 18-29.

[22] M. Vašák andG. Meloni, "Mammalian metallothionein-3: new functional and structural insights”,International Journal of Molecular Sciences, vol. 18, no. 6,(2017), pp. 1117.

[23] A. Ismail and R. Ramli, "Trace metals in sediments and molluscs from an estuary receiving pig farms effluent”,Environmental Health Perspectives, vol. 18, no. 5, (1997), pp. 509-515.

[24] S. Yusof, "Distribution and Accumulation of heavy metals in fish in cage system in Linggi estuary, Malaysia”. (MS Thesis),Universiti Putra Malaysia(2005).

[25] A.Y. Sow, A. Ismail andS.Z. Zulkifli, "Heavy metals uptake by Asian swamp eel, Monopterus albus from paddy fields of Kelantan, Peninsular Malaysia: Preliminary study”,Tropical Life Sciences Research, vol. 23, no. 2, (2012), pp. 27-38.

[26] A.J. Vickers, "Parametric versus non-parametric statistics in the analysis of randomized trials with nonnormally distributed data”,BMC Medical Research Methodology, vol. 5, no. 1, (2005), pp. 1-12. 
[27] J. Luengo, S. García andF. Herrera, “A study on the use of statistical tests for experimentation with neural networks: analysis of parametric test conditions and non-parametric tests”,Expert Systems with Applications, vol. 36, no. 4, (2009), pp. 7798-7808.

[28] V. Poleksic, M. Lenhardt, I. Jaric, D. Djordjevic, Z. Gacic, G. Cvijanovic andB. Raskovic, “Liver, gills, and skin histopathology and heavy metal content of the Danube sterlet (Acipenser ruthenus Linnaeus, 1758)”,Environmental Toxicology and Chemistry: An International Journal, vol. 29, no. 3,(2010),pp. 515-521.

[29] C. Hesse and E. Nortey, "Introduction to non parametric statistical methods", Akrong publications limited. Accra, Ghana, (2017).

[30] F. Rahman, A. Ismail and S. Yusof, "Metals contamination in the foraging area of Milky Stork: evidence of anthropogenic inputs in the aquatic environment of Kuala Gula, Malaysia”, Toxicological \& Environmental Chemistry,vol. 95, no. 9, (2013), pp. 1499-1505.

[31] B.Y. Kamaruzzaman, M.C. Ong andS.Z. Rina, "Concentration of $\mathrm{Zn}, \mathrm{Cu}$ and $\mathrm{Pb}$ in some selected marine fishes of the Pahang coastal waters, Malaysia”,American Journal of Applied Sciences, vol. 7, no. 3, (2010), pp. 309-314.

[32] A. Farkas, J. Salánki and A. Specziár, “Age- and size-specific patterns of heavy metals in the organs of freshwater fish Abramis brama L. populating a low-contaminated site”, Water Research, vol. 37, no. 5, (2003), pp. 959-964.

[33] Y.J. Yi andS.H. Zhang, "The relationships between fish heavy metal concentrations and fish size in the upper and middle reach of Yangtze river”,Procedia Environmental Sciences Procedia Environmental Sciences, vol.13, no. 8,(2012),pp. 1699-1707.

[34] S. Yin, "Bioaccumulation of heavy metals and Metallothionein effects on reproductive biology of Asian Swamp Eel (Monopterus albus Zuiew, 1793) in paddy fields in Tumpat,Kelantan, Malaysia”, (PhD Thesis), Universiti Putra Malaysia(2016).

[35] R.M. Lomoljo, "Diversity of migratory shorebirds and their habitat characteristics in Kuala Gula Bird Sanctuary, Perak, Malaysia”, (PhD Thesis), Universiti Putra Malaysia(2011).

[36] R. Scudiero, L. Cigliano and M. Verderame, “Age-related changes of metallothionein 1/2 and metallothionein 3 expression in rat brain”,Comptes Rendus Biologies, vol. 340, no. 1, (2017), pp. 1317.

[37] M. Sevcikova, H. Modra, K. Kruzikova, O. Zitka andD. Hynek, "Effect of Metals on Metallothionein Content in Fish from Skalka and Želivka Reservoirs”,Electrochem Science, vol. 8, no, 2, (2013), pp. 1650-1663.

[38] A. Naji, A. Ismail and E. Kamrani, "Correlation of MT levels in livers and gills with heavy metals in wild Tilapia (Oreochromis mossambicus) from the Klang river”,Bulletin of Environmental Contamination and Toxicology, vol. 92, no. 6, (2014), pp. 674-679.

[39] A. Aich, B. Chattopadhyay and S.K. Mukhopadhyay, "Immunolocalization of metallothionein in hepatocytes of guppy fish (Poecilia reticulata) exposed to tannery effluent: A biomarker study”,Chemosphere, vol. 169, (2017), pp. 460-466.

[40] J. Lee, H. Choi, U. Hwang, J. Kang, Y. Jai and J. Kim, "Toxic effects of lead exposure on bioaccumulation, oxidative stress, neurotoxicity, and immune responses in fish : Areview”,Environmental Toxicology and Pharmacology, vol. 68, no. 3,(2019), pp. 101-108.

[41] P.M. Costa, T. Repolho, S. Caeiro,M.E. Diniz, I. Moura and M.H. Costa, "Modelling metallothionein induction in the liver of (Sparus aurata) exposed to metal-contaminated sediments. Modelling metallothionein induction in the liver of Sparus aurata exposed to metal-contaminated sediments",Ecotoxicology and Environmental Eafety", vol. 71, no. 1,(2008),pp. 117-124. https://doi.org/10.1016/j.ecoenv.2007.05.012

[42] M. Lemus, I. Blanco, M. Hernández, A. León, L. Centeno andK. Chung, "Relation between metallothionein, RNA / DNA and heavy metals in juveniles of Colossoma macropomun (Cuvier, 1818) in natural conditions”,EDP Sciences, vol. 12001, (2013), pp. 2010-2013.

[43] C. Hogstrand and C. Haux, "Metallothionein as an indicator of heavy-metal exposure in two subtropical fish species”,Journal of Experimental Marine Biology and Ecology, vol. 138, no. 1\&2, (1990), pp. 69-84.

[44] B. Pula, T. Tazbierski, A. Zamirska, B. Werynska, A. Bieniek, J. Szepietowski and M. PodhorskaOkolow, "Metallothionein 3 expression in normal skin and malignant skin lesions”,Pathology \& Oncology Research, vol. 21, no. 1,(2015),pp.187-193.

[45] K.H. Tsui, C.P. Hou, K.S. Chang, Y.H. Lin, T.H. Feng, C.C. Chen and H.H. Juang, "Metallothionein 3 Is a Hypoxia-Upregulated Oncogene Enhancing Cell Invasion and Tumorigenesis in Human Bladder Carcinoma Cells”,International Journal of Molecular Sciences, vol. 20, no. 4, (2019), pp. 980.

[46] D. Rumahlatu, A.D. Corebima and M. Amin, "Activation, concentration, and expression of metallothionein-1 On Sea Urchin as biomonitoring heavy metal cadmium”,International Journal of Engineering and Science, vol. 3, no. 3. (2013), pp. 6-12.

[47] A. Gomulkiewicz, K. Jablonska, B. Pula, J. Grzegrzolka, S. Borska, M. Podhorska-Okolow and M. Zabel, "Expression of metallothionein 3 in ductal breast cancer",International Journal of Oncology, vol. 49, no. 6, (2016), pp. 2487-2497. 